\title{
Systematic Review \\ The Expression and Regulatory Roles of Long Non-Coding RNAs in Periodontal Ligament Cells: A Systematic Review
}

\author{
Yifan Lin ${ }^{1,+}$, , Zhongyuan Tang ${ }^{1,+}$, Lijian Jin $^{2} \mathbb{D}$ and Yanqi Yang ${ }^{1, *}$ \\ 1 Division of Paediatric Dentistry and Orthodontics, Faculty of Dentistry, The University of Hong Kong, \\ Hong Kong, China; yflin@hku.hk (Y.L.); tzy337@connect.hku.hk (Z.T.) \\ 2 Division of Periodontology and Implant Dentistry, Faculty of Dentistry, The University of Hong Kong, \\ Hong Kong, China; ljij@@hku.hk \\ * Correspondence: yangyanq@hku.hk \\ + These authors contributed equally to this work.
}

check for updates

Citation: Lin, Y.; Tang, Z.; Jin, L.; Yang, Y. The Expression and

Regulatory Roles of Long

Non-Coding RNAs in Periodontal

Ligament Cells: A Systematic Review.

Biomolecules 2022, 12, 304. https://

doi.org/10.3390/biom12020304

Academic Editor: Atsushi Saito

Received: 10 January 2022

Accepted: 9 February 2022

Published: 12 February 2022

Publisher's Note: MDPI stays neutral with regard to jurisdictional claims in published maps and institutional affiliations.

Copyright: (C) 2022 by the authors. Licensee MDPI, Basel, Switzerland. This article is an open access article distributed under the terms and conditions of the Creative Commons Attribution (CC BY) license (https:// creativecommons.org/licenses/by/ $4.0 /)$.

\begin{abstract}
Periodontal ligament (PDL) cells play a pivotal role in periodontal and bone homeostasis and have promising potential for regenerative medicine and tissue engineering. There is compelling evidence that long non-coding RNAs (lncRNAs) are differentially expressed in PDL cells compared to other cell types and that these lncRNAs are involved in a variety of biological processes. This study systematically reviews the current evidence regarding the expression and regulatory functions of lncRNAs in PDL cells during various biological processes. A systematic search was conducted on PubMed, the Web of Science, Embase, and Google Scholar to include articles published up to 1 July 2021. Original research articles that investigated the expression or regulation of lncRNAs in PDL cells were selected and evaluated for a systematic review. Fifty studies were ultimately included, based on our eligibility criteria. Thirteen of these studies broadly explored the expression profiles of lncRNAs in PDL cells using microarray or RNA sequencing. Nineteen studies investigated the mechanisms by which lncRNAs regulate osteogenic differentiation in PDL cells. The remaining 18 studies investigated the mechanism by which lncRNAs regulate the responses of PDL cells to various stimuli, namely, lipopolysaccharide-induced inflammation, tumor necrosis factor alphainduced inflammation, mechanical stress, oxidative stress, or hypoxia. We systematically reviewed studies on the expression and regulatory roles of lncRNAs in diverse biological processes in PDL cells, including osteogenic differentiation and cellular responses to inflammation, mechanical stress, and other stimuli. These results provide new insights that may guide the development of lncRNA-based therapeutics for periodontal and bone regeneration.
\end{abstract}

Keywords: long non-coding RNA; periodontal ligament cells; osteogenic differentiation; inflammation; mechanical stress

\section{Introduction}

Periodontitis is a plaque-induced inflammatory oral disease that causes the progressive breakdown of periodontal tissue, and it is one of the leading causes of tooth loss [1,2]. Although conventional therapies can control active periodontal inflammation, they are unable to fully regenerate damaged periodontal tissue. Therefore, recent efforts to treat periodontal diseases have focused on regenerative therapies that can restore the physiological function of teeth by re-building supporting periodontium, including periodontal ligament (PDL), alveolar bone, gingiva, and cementum [3,4].

PDL is a thin layer of fibrous connective tissue, located between the alveolar bone and cementum, that plays a crucial role in the development, functioning, and regeneration of the tooth-supporting apparatus. An early study of PDL found that it had a regenerative capacity and possibly contained a population of multipotent progenitor cells [5]. It has since been established that PDL cells are a heterogeneous cell population consisting of fibroblastic and osteoblastic mesenchymal lineages that include cells at different stages of 
differentiation and lineage commitment [6-11]. PDL stem cells (PDLSCs) were first isolated in 2004 [12] and have been shown to exhibit self-renewal ability and multipotent capacities. Numerous in vitro studies have revealed that PDLSCs can differentiate into various types of cells, including adipocytes, osteoblasts, chondrocytes, neurons, and hepatocytes [12-15]. Moreover, in vivo models have demonstrated that PDLSCs form cementum- and PDLlike structures after transplantation into surgically created periodontal defects, which suggests that they could be used for the regeneration of periodontal tissues [16-18]. A study comparing PDL cells with PDLSCs revealed that PDL cells were similar to PDLSCs in that they have a high proliferative capacity and multipotent differentiation abilities, express mesenchymal surface markers, and can regenerate periodontal tissues in vivo [19]. This study also demonstrated the feasible and safe application of autologous PDL cells for periodontal regenerative treatment in patients diagnosed with periodontitis [19].

RNAs are versatile biomolecules that are either protein-coding (coding) or non-proteincoding (non-coding) RNAs. Non-coding RNAs, which are not translated into proteins, are classified as housekeeping RNAs (e.g., ribosomal RNAs, transfer RNAs, and small nuclear RNAs) and regulatory RNAs [20]. Regulatory RNAs are further classified based on their length into short and long non-coding RNAs (lncRNAs). MicroRNAs (miRNAs) are short non-coding RNAs that are generally 20 to 23 nucleotides in length, and they function as post-transcriptional repressors by binding to messenger RNA (mRNA), which results in the silencing of a specific target gene.

LncRNAs have received much attention in recent years and comprise a large and diverse class of transcribed RNA molecules that are greater than 200 nucleotides in length. It was discovered that these lncRNAs, which were once considered "transcriptional noise" in the genome, may play critical regulatory roles in many biological processes [21]. However, due to their low conservation, high level of alternatively spliced transcripts, and tissueand development-specific expression, most lncRNAs remain unannotated and are yet to be ascribed any function [10]. LncRNAs typically interact with DNA, RNA, protein molecules, and/or combinations thereof to regulate gene expression at transcriptional and post-transcriptional levels [22].

Studies have indicated that lncRNAs are involved in and may be vital to a variety of diseases associated with aberrant cellular control, including autoimmune, neurological and cardiovascular conditions, and cancers [23-26]. In recent years, the role of lncRNAs in the regulation of PDL cells has attracted increasing attention. There is substantive evidence that lncRNAs are differentially expressed in PDL cells compared to other cell types and are also differentially expressed during various biological functions [27-30]. In addition, several lncRNAs, such as maternally expressed gene 3 (MEG3), anti-differentiation non-coding RNA (ANCR), and taurine upregulated gene 1 (TUG1), have been found to regulate the regenerative capacities of PDL cells under normal and inflammatory conditions [31-33].

The significant progress made toward elucidating the biogenesis and functions of lncRNAs has afforded ample evidence for their critical roles in many biological pathways. The present study systematically reviews articles on the expression and regulatory roles of lncRNAs in PDL cells during a variety of biological processes.

\section{Materials and Methods}

\subsection{Search Strategy}

A systematic search for studies was conducted in four databases (PubMed, ClarivateWeb of Science, Google Scholar, and Embase) from the date of their respective inception to 1 July 2021. The search terms used were as follows: ("periodontal ligament cell" OR "periodontal ligament stem cell" OR "periodontal ligament fibroblast" OR "PDL cell" OR "PDLSC" OR "PDLC" OR "hPDLSC" (human PDLSC) OR "hPDLC" (human PDLC) OR "hPDL cell" (human PDL cell) AND “long non-coding RNA" OR "long noncoding RNA" OR "lncRNA". 


\subsection{Selection Criteria}

The inclusion criteria were as follows: (1) studies based on cell, human, or animal models; (2) studies related to the expression or regulation of lncRNAs in PDL cells; and (3) studies published in English. The exclusion criterion was as follows: reviews, conference abstracts, or editorials.

\subsection{Selection of Studies}

Titles and abstracts of manuscripts were independently screened in electronic sheets by two reviewers (Y.L. and Z.T.). Titles and abstracts were examined, and duplicate studies were eliminated. If an article's abstract did not contain sufficient information for an inclusion/exclusion decision to be made, its full text was obtained and carefully inspected. Any inter-examiner disagreement was resolved by discussion. The level of agreement between the two examiners was assessed by determining Cohen's kappa scores.

\subsection{Quality Assessment}

The quality of selected papers was evaluated using a well-known system (Table S1) described by Wells and Littell [34]. The following eight questions comprised the quality scoring system. (1) Was the study hypothesis/aim/objective clearly described? (2) Were the experimental designs in the study well described? (3) Were the methods and materials in the study well described? (4) Were the time-points of data collection in the study clearly defined? (5) Were the main outcomes of measurements in the study clearly defined? (6) Were the experimental groups comprehensively compared with the control group in the study? (7) Were the results in the study well described? (8) Were the limitations of the study discussed? In answering each question, 1 point was allocated for "yes" and 0 points were allocated for "no." The sum of scores for each study was calculated independently, and the total possible score was 8 . A score of 7 to 8 indicates a study with excellent quality, a score of 5 to 6 indicates a good quality study, a score of 3 to 4 indicates a low-quality study, and a score of 0 to 2 indicates a bad quality study. A detailed evaluation of the scores of selected studies is presented in Table S1.

\section{Results}

\subsection{Literature Search and Screening of Studies}

A flow diagram of study selection is shown in Figure 1. Two hundred and eighty records were obtained by screening titles and abstracts and removing duplicates. After reviewing these titles and abstracts, 73 articles were retrieved for full-text evaluation, and 23 were subsequently excluded for the reasons described in the diagram. The remaining 50 studies were included for further analysis. The kappa score for study selection was 0.939 , indicating that there was an excellent level of agreement between the reviewers. All studies were published between 2014 and 2021, and their characteristics are summarized in Figure 2 .

\subsection{Studies on IncRNA Expression Profiling in PDL Cells}

In total, 13 of the 50 studies broadly explored the expression profiling of PDL cells using microarray or RNA sequencing (RNA-seq) (Table 1). These studies investigated the IncRNA expression profiles of PDL cells subjected to osteogenic induction $[28-30,35,36]$ and mechanical stress [37-41]; some compared PDL cells' expression profiles with those of other cell types, including bone marrow stem cells (BMSCs) [27], gingival mesenchymal stem cells (GMSCs) [42], and dental follicle cells (DFCs) [43]. 


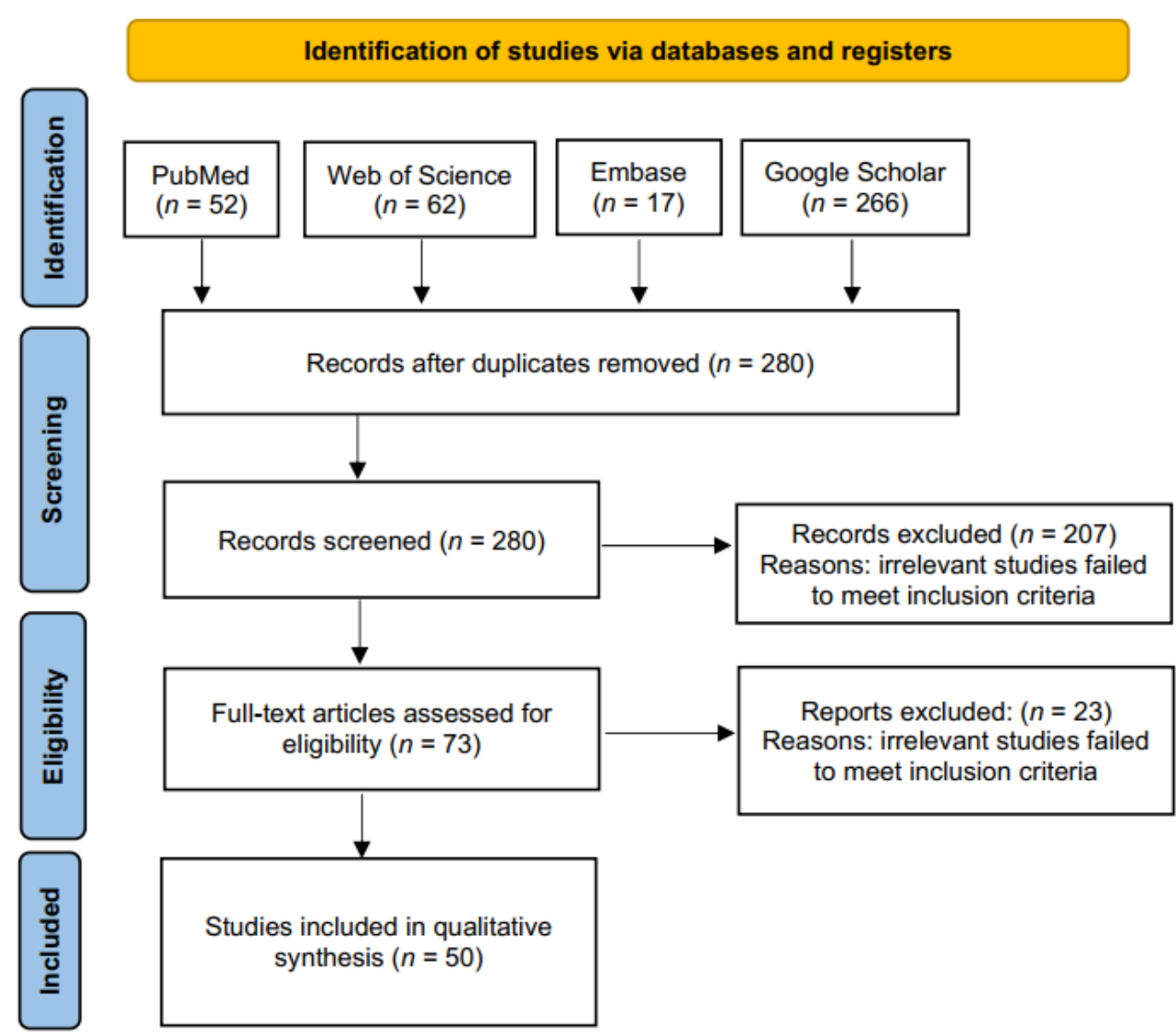

Figure 1. Flow diagram of the process of study selection. Two hundred and eighty studies were retrieved based on the search strategy described in the methodology. After reviewing the titles and abstracts of these studies, 73 studies were obtained. After reviewing the full text of these studies, 50 studies met the criteria for inclusion in this systematic review.

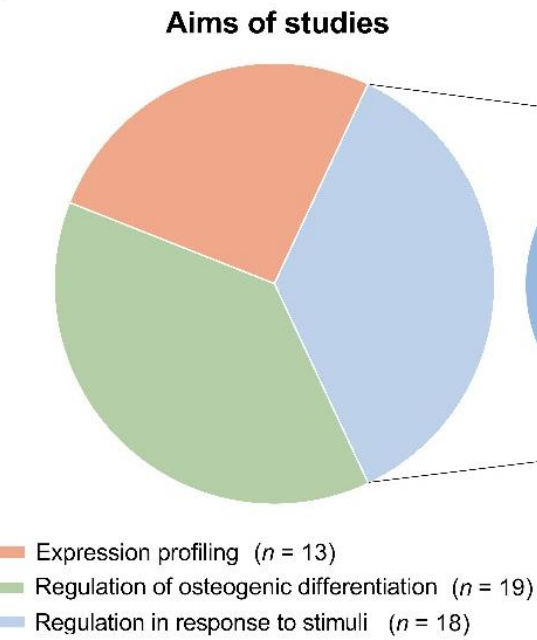

Total $=50$

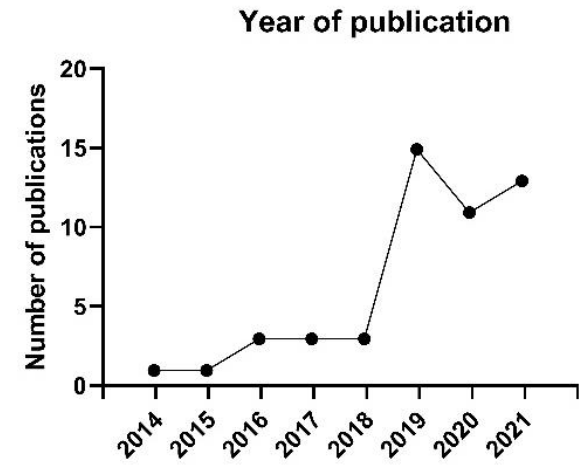

Figure 2. Characteristics of the studies included in the systematic review. (a) Aims of the included studies and types of stimuli. (b) Distribution of years of publication of included studies. 
Table 1. Studies on expression profiling of lncRNAs in PDLSCs.

\begin{tabular}{|c|c|c|c|}
\hline Study & Samples and Stimulation & $\begin{array}{l}\text { Differential Expression of lncRNAs in } \\
\text { PDL Cells }\end{array}$ & qPCR Validation \\
\hline [27] & 3 PDLSC and 3 BMSC samples & $457 \uparrow$ and $513 \downarrow \operatorname{lncRNAs}$ in PDLSCs & $\begin{array}{c}\uparrow: \text { NR045555, NR027621, NR03365; } \\
\downarrow: \text { NR037182, NR037595, XR111050 } \\
\text { (in PDLSCs) }\end{array}$ \\
\hline [28] & $\begin{array}{l}\text { osteogenic-induced and } \\
\text { non-induced PDLSC samples }\end{array}$ & $\begin{array}{l}777 \uparrow \text { and } \downarrow \text { lncRNAs in induced PDLSCs } \\
\quad(\mid \text { fold change } \mid \geq 2 \text { and } p<0.05)\end{array}$ & $\begin{array}{c}\uparrow: \text { TCONS_00019601, } \\
\text { TCONS_00227764, TCONS_00254538, } \\
\text { TCONS_00198784, TCONS_00136898; } \\
\downarrow \downarrow \text { : TCONS_00085268, } \\
\text { TCONS_00125934, TCONS_00115113 }\end{array}$ \\
\hline
\end{tabular}

3 osteogenic-induced samples, 3 osteogenic- and

[29] TNF $\alpha$-stimulated samples, and 3 noninduced/stimulated samples

[30] osteogenic-induced and non-induced PDLSC samples
$214 \uparrow$ and $193 \downarrow \operatorname{lncRNAs}$ in

osteogenic-induced PDLSCs;

$149 \uparrow$ and $169 \downarrow$ lncRNAs in TNF $\alpha$ - and osteogenic-induced PDLSCs compared to non-induced PDLSCs (log2 fold-change $\geq 1$ and adjusted $p \leq 0.05)$.

10,36 and $69 \uparrow$ and 44,11 and $70 \downarrow$ lncRNAs after 3 days, 7 days, and 14 days of osteogenic induction, respectively (fold-change $\geq 2$ and adjusted $p<0.05$ )

$994 \uparrow$ and $1177 \downarrow$ lncRNAs in induced PDLSCs ( $\mid$ fold change $\mid \geq 2$ and $p<0.05$ )

$118(70 \uparrow$ and $48 \downarrow)$ and $43(24 \uparrow$ and $19 \downarrow)$ lncRNAs after 5 or 7 days of osteogenic induction, respectively $(p<0.05$ and $\log 2$ fold-change $>1)$.
个: LINC-PDE10A-1, GK-AS-1;

$\downarrow:$ ZNF385D-AS-1, SGOL1-AS-1

\begin{tabular}{|c|c|c|c|}
\hline [35] & $\begin{array}{l}3 \text { osteogenic-induced and } \\
3 \text { non-induced PDLSC } \\
\text { samples from } 15 \text { individuals }\end{array}$ & $\begin{array}{l}994 \uparrow \text { and } 1177 \downarrow \text { lncRNAs in induced PDLSCs } \\
(\mid \text { fold change } \mid \geq 2 \text { and } p<0.05)\end{array}$ & $\begin{array}{l}\uparrow: \text { AC078851.1, RP11-45A16.4, } \\
\text { XLOC_002932, RP4-613B23.1, } \\
\text { RP11305L7.6 }\end{array}$ \\
\hline [36] & $\begin{array}{l}\text { osteogenic-induced and } \\
\text { non-induced exosomes } \\
\text { derived from PDLSCs }\end{array}$ & $\begin{array}{c}118(70 \uparrow \text { and } 48 \downarrow) \text { and } 43(24 \uparrow \text { and } 19 \downarrow) \\
\text { lncRNAs after } 5 \text { or } 7 \text { days of osteogenic } \\
\text { induction, respectively }(p<0.05 \text { and log } 2 \\
\text { fold-change }>1) \text {. }\end{array}$ & $\begin{array}{l}\text { SNHG5, LOC100130992, and } \\
\text { ATP6V1B1-AS1: no } \\
\text { significant difference. }\end{array}$ \\
\hline [37] & $\begin{array}{l}3 \text { orthodontic force-induced } \\
\text { and } 3 \text { non-induced } \\
\text { PDL samples }\end{array}$ & $\begin{array}{l}\text { DLEU2 } \uparrow \text { and DNAJC3-AS1 } \downarrow \text { in induced PDL } \\
\text { samples }(p \leq 0.05)\end{array}$ & / \\
\hline [38] & $\begin{array}{l}\text { compressive force-induced } \\
\text { and non-induced PDLSCs }\end{array}$ & $\begin{array}{c}72 \uparrow \text { and } 18 \downarrow \operatorname{lncRNAs} \text { in } \\
\text { compression-induced PDLSCs (adjusted } \\
p<0.05 \text { and fold-change }>1.5 \text { ) }\end{array}$ & $\begin{array}{l}\uparrow: \text { FER1L4, HIF1A-AS2, MIAT, } \\
\text { NEAT1, ADAMTS9-AS2, LUCAT1; } \\
\downarrow: \text { MIR31HG and DHFRP1 }\end{array}$ \\
\hline [39] & $\begin{array}{c}5 \text { tension-induced and } 5 \\
\text { non-induced PDL cell samples }\end{array}$ & $\begin{array}{l}107 \uparrow \text { and } 88 \downarrow \operatorname{lncRNAs} \text { in } \\
\text { tension-induced-PDL cells (adjusted } p<0.05 \text { ) }\end{array}$ & ^: MIR22HG, CYTOR, SNHG3 \\
\hline [40] & $\begin{array}{l}3 \text { H-PDLSC and } 3 \\
\text { P-PDLSC samples }\end{array}$ & $\begin{array}{l}\text { ENST00000411904 the most } \uparrow \operatorname{lncRNA} \text { in } \\
\text { strained H-PDLSCs; lncRNA-XIST and } \\
\text { ENST0000051750 the most } \uparrow \text { and } \downarrow \text { lncRNAs } \\
\text { in strained P-PDLSCs, respectively. }\end{array}$ & $\begin{array}{c}\downarrow: \text { TCONS_00008604, } \\
\text { ENST00000428781, uc004arq.1, XIST }\end{array}$ \\
\hline [41] & $\begin{array}{l}\text { tensile force-induced and } \\
\text { non-induced PDLSC }\end{array}$ & $\begin{array}{l}799 \uparrow \text { and } 540 \downarrow \text { lncRNAs in tension-induced } \\
\text { PDLSC }(p<0.05 \text {, fold-change }>2)\end{array}$ & 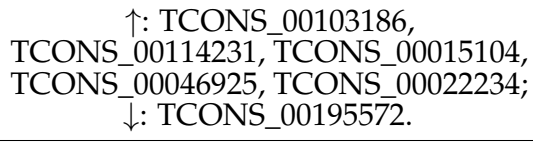 \\
\hline [42] & $\begin{array}{l}3 \text { PDLSC and } 3 \\
\text { GMSC samples }\end{array}$ & $\begin{array}{l}735 \uparrow \text { and } 1427 \downarrow \text { lncRNAs in PDLSCs } \\
\text { (fold-change } \geq 1.2 \text { ). }\end{array}$ & 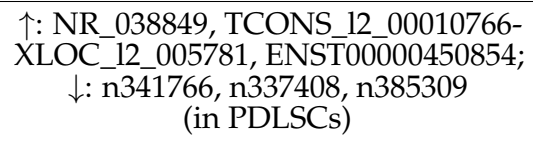 \\
\hline [43] & $\begin{array}{l}\text { PDL cell and DFC samples } \\
\text { from } 4 \text { individuals }\end{array}$ & $385 \uparrow$ and $460 \downarrow$ lncRNAs in PDL cells & $\begin{array}{c}\uparrow: \text { NR_033917, NR_038367, } \\
\text { NR_026861; } \\
\downarrow N R \_102703, \text { NR_110162, } \\
\text { ENST00000430859 (in PDL cells) }\end{array}$ \\
\hline
\end{tabular}

$\uparrow:$ increased, $\downarrow$ : decreased, bone-marrow stem cell (BMSC), cytoskeleton regulator RNA (CYTOR), dental follicle cells (DFC), gingival mesenchymal stem cell (GMSC), hypoxia-inducible factor 1 alpha-antisense RNA 2 (HIF1A-AS2), MIR31 host gene (MIR31HG), periodontal ligament (PDL), periodontal ligament stem cell (PDLSC), quantitative polymerase chain reaction (PCR), X-inactive-specific transcript (XIST).

\subsection{Studies on IncRNAs Involved in the Osteogenic Differentiation of PDL Cells}

Table 2 presents 19 studies that investigated the mechanism by which lncRNAs regulate the osteogenic differentiation of PDL cells. Fifteen of these studies investigated PDL cells from healthy individuals (henceforth denoted as H-PDL cells or H-PDLSCs) [31-33,44-59], whereas four of these studies isolated PDL cells from patients with periodontitis (henceforth denoted 
as P-PDL cells or P-PDLSCs) to determine the regulatory role of lncRNAs in osteogenesis under inflammatory conditions $[33,45,50,58]$.

Table 2. Studies on the regulatory mechanisms of lncRNAs in PDLSCs during osteogenic differentiation.

\begin{tabular}{|c|c|c|c|c|}
\hline Study & lncRNAs & $\begin{array}{l}\text { Increased }(\uparrow) \text { or Decreased }(\downarrow) \\
\text { Expression in PDL Cells } \\
\text { upon Stimulation }\end{array}$ & $\begin{array}{c}\text { Effect on } \\
\text { Osteogenesis }\end{array}$ & $\begin{array}{l}\text { Effect on the Associated } \\
\text { Signaling Pathway }\end{array}$ \\
\hline$[31,44,47]$ & ANCR & $\downarrow$ upon osteogenic induction & $\downarrow$ & $\begin{array}{l}\text { inhibition of miR-758, which upregulates } \\
\text { Notch2- Wnt/ } \beta \text {-catenin; inhibition of the } \\
\text { Wnt / } \beta \text {-catenin signaling pathway }\end{array}$ \\
\hline [54] & DANCR & $\downarrow$ upon osteogenic induction & $\downarrow$ & / \\
\hline$[52]$ & FER1L4 & $\uparrow$ upon osteogenic induction & $\uparrow$ & $\begin{array}{c}\text { inhibition of miR-874-3p, which regulates } \\
\text { the VEGFA axis }\end{array}$ \\
\hline [56] & GAS5 & $\uparrow$ upon osteogenic induction & $\uparrow$ & $\begin{array}{l}\text { upregulation of GDF5, which decreases } \\
\text { the phosphorylation of p38/JNK }\end{array}$ \\
\hline [46] & HIF1A-AS2 & $\uparrow$ upon hypoxia & $\downarrow$ & inhibition of HIF- $1 \alpha$ \\
\hline [58] & LncRNA ANRIL & $\downarrow$ in P-PDLSCs & $\uparrow$ & $\begin{array}{l}\text { inhibition of miR-7-5p, which regulates } \\
\text { the IGF-1R axis }\end{array}$ \\
\hline [45] & LncRNA-POIR & $\begin{array}{l}\downarrow \text { in P-PDLSCs, } \uparrow \text { upon } \\
\text { osteogenic induction }\end{array}$ & $\uparrow$ & $\begin{array}{c}\text { inhibition of miR-182, which } \\
\text { downregulates the FoxO1/canonical } \\
\text { Wnt pathway }\end{array}$ \\
\hline$[50]$ & LncRNA-TWIST1 & $\begin{array}{l}\downarrow \text { in P-PDLSCs, } \uparrow \text { upon } \\
\text { osteogenic induction }\end{array}$ & $\uparrow$ & $\begin{array}{l}\text { activation of the } \mathrm{Wnt} / \beta \text {-catenin } \\
\text { signaling pathway }\end{array}$ \\
\hline$[33]$ & MEG3 & $\begin{array}{c}\downarrow \text { in P-PDLSCs, } \uparrow \text { upon } \\
\text { osteogenic induction in PDLSCs }\end{array}$ & $\uparrow$ & $\begin{array}{c}\text { inhibition of miR-27a-3p, which regulates } \\
\text { the IGF1 axis-regulated PI3K/AKT } \\
\text { signaling pathway }\end{array}$ \\
\hline [49] & MEG3 & $\downarrow$ upon osteogenic induction & $\downarrow$ & $\begin{array}{l}\text { competes with BMP2 mRNA for } \\
\text { RBP hnRNPI }\end{array}$ \\
\hline$[48]$ & PCAT1 & $\uparrow$ upon osteogenic induction & $\uparrow$ & $\begin{array}{l}\text { inhibition of miR-106a-5p, which } \\
\text { regulates the BMP2 and E2F5 } \\
\text { feed-forward regulatory network }\end{array}$ \\
\hline [59] & PWAR6 & $\uparrow$ upon osteogenic induction & $\uparrow$ & $\begin{array}{c}\text { inhibition of miR-106a-5, which regulates } \\
\text { the BMP2 axis }\end{array}$ \\
\hline [53] & SNHG1 & $\downarrow$ upon osteogenic induction & $\downarrow$ & $\begin{array}{l}\text { activation of H3K27 trimethylation of the } \\
\text { KLF2 promoter }\end{array}$ \\
\hline$[32,55]$ & TUG1 & $\uparrow$ upon osteogenic induction & $\uparrow$ & $\begin{array}{l}\text { inhibition of miR-222-3p, which } \\
\text { downregulates the Smad2/7 ceRNA } \\
\text { regulatory network; binding the } \\
\text { RNA-binding protein (RBP) Lin28A }\end{array}$ \\
\hline [51] & XIST & $\uparrow$ upon osteogenic induction & $\uparrow$ & inhibition of the miR-214-3p axis \\
\hline [57] & $\begin{array}{l}\text { XPO5, HOTAIR, } \\
\text { HOTTIP }\end{array}$ & $\begin{array}{l}\downarrow \text { in PDLSCs with high } \\
\text { osteogenic potentials }\end{array}$ & $\downarrow$ & / \\
\hline
\end{tabular}

$\uparrow$ : increased, $\downarrow$ : decreased, anti-differentiation non-coding RNA (ANCR), antisense non-coding RNA in the INK4 locus (ANRIL), bone morphogenetic protein 2 (BMP2), differentiation antagonizing non-coding RNA (DANCR), exportin 5 (XPO5), Fer-1-like family member 4 (FER1L4), forkhead box protein O1 (FOXO1), growth arrest-specific transcript 5 (GAS5), heterogeneous nuclear ribonucleoprotein I (hnRNPI), histone H3 lysine 27 (H3K27), HOX transcript antisense RNA (HOTAIR), HOXA transcript at the distal tip (HOTTIP), hypoxia-inducible factor 1 alpha-antisense RNA 2 (HIF1A-AS2), insulin-like growth factor 1 (IGF1), Kruppel-like factor 2 (KLF2), Lin-28 homolog A (Lin28A), maternally expressed gene 3 (MEG3), osteogenesis impairment-related lncRNA of PDLSCs from periodontitis patients (lncRNA-POIR), phosphatidylinositol 3-kinase (PI3K), Prader Willi/Angelman region RNA 6 (PWAR6), prostate cancer-associated transcript 1 (PCAT1), protein kinase B (AKT), small molecule RNA host gene 1 (SNHG1), taurine-upregulated gene 1 (TUG1), X-inactive-specific transcript (XIST).

\subsection{Studies on IncRNAs in PDL Cells Subjected to Inflammation, Mechanical Stress, and Other Stimuli}

Table 3 presents 18 studies that investigated the role of lncRNAs in regulating cellular processes in PDL cells in the presence or absence of stimuli, including studies that compared H-PDL and P-PDL cells [60-65]. These studies also explored the role of IncRNAs in lipopolysaccharide (LPS)-induced inflammation [66-71], tumor necrosis factor-alpha 
(TNF- $\alpha$ )-induced inflammation [72], mechanical stress [73-75], hypoxia [76], and oxidative stress [77]. To review the outcomes of lncRNA involvement, cell proliferation, apoptosis, inflammatory responses, autophagy, migration, and root resorption were examined.

Table 3. Studies on the regulatory mechanisms of lncRNAs in PDL cells in response to inflammation, mechanical loading, and other stimuli.

\begin{tabular}{|c|c|c|c|c|c|}
\hline Study & lncRNAs & $\begin{array}{c}\text { Increased }(\uparrow) \text { or } \\
\text { Decreased }(\downarrow) \\
\text { Expression in PDLSCs } \\
\text { upon Stimulation }\end{array}$ & $\begin{array}{l}\text { Effect on PDLSCs } \\
\text { upon Stimulation }\end{array}$ & $\begin{array}{l}\text { Regulatory } \\
\text { Mechanism }\end{array}$ & $\begin{array}{c}\text { Associated Signaling Pathways or } \\
\text { Biomarkers }\end{array}$ \\
\hline [73] & DANCR & $\begin{array}{l}\uparrow \text { in H-PDL cells under } \\
\text { compressive force }\end{array}$ & $\uparrow$ root resorption & miR-34a-5p/jagged1 & $\begin{array}{l}\text { silences DANCR, downregulates } \\
\text { number of TRAP-positive osteoclasts } \\
\text { and the expression of RANKL. }\end{array}$ \\
\hline$[65]$ & DCST1-AS1 & $\downarrow$ in P-PDL cells & $\downarrow$ proliferation & miR-21/PLAP-1 & $\downarrow$ CDK4, CDK6, CCND1; $\uparrow$ PLAP-1 \\
\hline$[75]$ & FER1L4 & $\begin{array}{l}\uparrow \text { in H-PDLSC under } \\
\text { compressive force }\end{array}$ & $\uparrow$ autophagy & $\begin{array}{l}\text { AKT/FOXO3 signaling } \\
\text { pathway }\end{array}$ & $\begin{array}{l}\uparrow \mathrm{LC} 3 \mathrm{II} / \mathrm{I}, \text { Beclin } 1 \text {, autophagosomes, } \\
\text { autolysosomes; } \downarrow \text { p-FOXO3, p-AKT }\end{array}$ \\
\hline$[66]$ & FGD5-AS1 & $\begin{array}{c}\downarrow \text { in P-PDL cells and } \\
\text { LPS-induced H-PDL cells }\end{array}$ & $\begin{array}{l}\uparrow \text { proliferation; } \downarrow \\
\text { apoptosis }\end{array}$ & $\begin{array}{l}\text { miR-142- } \\
\text { 3p/SOCS6/NF-кB } \\
\text { pathway }\end{array}$ & $\begin{array}{c}\downarrow \mathrm{p} / \mathrm{t}-\mathrm{p} 65, \mathrm{BAX} / \mathrm{Bcl}-2, \\
\text { cleaved/pro-caspase-3, } \\
\text { cleaved } / \text { pro-caspase-9, TNF- } \alpha, \text { IL-6, } \\
\text { IL-1 } \beta, \text { and IL-8; } \uparrow \mathrm{p} / \mathrm{t}-\mathrm{I} \kappa \mathrm{B} \alpha\end{array}$ \\
\hline$[72]$ & H19 & $\begin{array}{l}\uparrow \text { in TNF- } \alpha \text { and } \\
\text { LPS-induced H-PDL cells }\end{array}$ & $\uparrow$ autophagy & $\begin{array}{c}\text { PI3K/AKT } \\
\text { signaling pathway. }\end{array}$ & $\begin{array}{c}\uparrow \text { Beclin-1, LC3 II/I, TNF- } \alpha \text {, and } \\
\text { IL-6; } \downarrow \text { p-AKT }\end{array}$ \\
\hline$[77]$ & $\begin{array}{l}\text { JHDM1D- } \\
\text { AS1 }\end{array}$ & $\begin{array}{c}\downarrow \text { in } \mathrm{H}_{2} \mathrm{O}_{2} \text {-induced } \\
\mathrm{H}-\mathrm{PDLSC}\end{array}$ & $\downarrow$ apoptosis & $\begin{array}{l}\mathrm{DNAJC} 10 / \mathrm{p}- \\
\mathrm{eIF} 2 \alpha / \mathrm{Bcl}-2 \\
\text { regulatory axis }\end{array}$ & $\begin{array}{c}\downarrow \text { cleaved-caspase } 3 \text {, cleaved-caspase } \\
9, \text { BAK, ROS, DNAJC10; } \uparrow \text { p-PERK, } \\
\text { p-eIF2 } \alpha, \text { Bcl-2/BAX }\end{array}$ \\
\hline$[69]$ & LINC01126 & $\begin{array}{l}\uparrow \text { in LPS-induced } \\
\text { H-PDL cells }\end{array}$ & $\begin{array}{c}\uparrow \text { inflammation; } \\
\downarrow \text { migration }\end{array}$ & $\begin{array}{c}\text { MEK/ERK } \\
\text { signaling pathway }\end{array}$ & $\downarrow \mathrm{p} / \mathrm{t}-\mathrm{MEK}$ and $\mathrm{p} / \mathrm{t}-\mathrm{ERK}$. \\
\hline [76] & LINC01126 & $\begin{array}{l}\uparrow \text { in hypoxia-induced } \\
\text { H-PDL cells }\end{array}$ & $\begin{array}{l}\uparrow \text { apoptosis, } \\
\text { inflammation; } \downarrow \\
\text { proliferation }\end{array}$ & $\begin{array}{c}\text { miR-518a-5p/HIF- } \\
1 \alpha / \mathrm{MAPK} \\
\text { pathway }\end{array}$ & $\begin{array}{c}\uparrow \text { p38, ERK1/2, JNK, IL-1 } \beta, \text { IL-6, } \\
\text { IL-8, TNF- } \alpha .\end{array}$ \\
\hline$[64]$ & Linc-RAM & $\downarrow$ in P-PDLSC & $\uparrow$ proliferation & $\begin{array}{l}\text { inhibits the effect of } \\
\text { overexpression of FGF2 } \\
\text { on proliferation }\end{array}$ & / \\
\hline$[63]$ & MAFG-AS1 & $\downarrow$ in P-PDLSC & $\begin{array}{c}\uparrow \text { inflammation; } \downarrow \\
\text { proliferation }\end{array}$ & miR-146a/TLR4 axis & $\uparrow$ TLR4 \\
\hline$[60]$ & MALAT1 & $\uparrow$ in P-PDLSC & $\uparrow$ proliferation & FGF2 axis & $\uparrow$ FGF2 \\
\hline$[70]$ & MALAT1 & $\begin{array}{l}\uparrow \text { in LPS-induced } \\
\text { H-PDL cells }\end{array}$ & $\begin{array}{l}\uparrow \text { apoptosis, } \\
\text { inflammation } \\
\downarrow \text { proliferation }\end{array}$ & $\begin{array}{l}\text { miR-769- } \\
\text { 5p/HIF3A axis }\end{array}$ & $\begin{array}{c}\uparrow \text { IL-6, IL- } 1 \beta, \text { TNF- } \alpha, \text { BAX, and } \\
\text { caspase- } 3 ; \uparrow \text { Bcl-2. }\end{array}$ \\
\hline$[68]$ & MEG3 & $\begin{array}{c}\downarrow \text { in P-PDL cells and } \\
\text { LPS-induced H-PDL cells }\end{array}$ & $\begin{array}{l}\uparrow \text { proliferation; } \downarrow \\
\text { apoptosis, } \\
\text { inflammation }\end{array}$ & $\begin{array}{c}\text { miR-143-3p } \\
\text { AKT /IKK pathway }\end{array}$ & $\begin{array}{c}\downarrow \text { p-AKT } / \text { AKT, p-IKK/IKK, p-p65, } \\
\text { IL-6, IL-18, IL-1 } \beta, \text { TNF- } \alpha .\end{array}$ \\
\hline$[74]$ & MIR31HG & $\begin{array}{l}\downarrow \text { in H-PDLSC under } \\
\text { compressive force }\end{array}$ & $\uparrow$ proliferation & $\begin{array}{l}\text { DNMT1 and DNMT3B } \\
\text { inhibited expression } \\
\text { of MIR31HG }\end{array}$ & $\begin{array}{l}\text { silences MIR31HG, inhibits } \\
\text { cell viability. }\end{array}$ \\
\hline$[62]$ & MORT & $\downarrow$ in P-PDLSC & $\downarrow$ proliferation & & inhibits cell viability \\
\hline$[61]$ & PTCSC3 & $\downarrow$ in P-PDL cells & $\downarrow$ proliferation & TLR4 & $\downarrow$ TLR4 \\
\hline$[67,71]$ & TUG1 & $\begin{array}{c}\downarrow \text { in P-PDL cells and } \\
\text { LPS-induced H-PDL cells }\end{array}$ & $\begin{array}{l}\uparrow \text { proliferation; } \downarrow \\
\text { apoptosis, } \\
\text { inflammation }\end{array}$ & $\begin{array}{c}\text { miR-498/RORA axis } \\
\text { and Wnt / } \beta \text {-catenin } \\
\text { signaling pathway; } \\
\text { miR-132 axis }\end{array}$ & $\begin{array}{c}\downarrow \beta \text {-catenin, } \mathrm{p} / \mathrm{t}-\mathrm{GSK}-3 \beta, \mathrm{p} 21, \mathrm{TNF}-\alpha, \\
\mathrm{IL}-1 \beta, \mathrm{IL}-6, \text { and IL- } 8 ; \uparrow \text { CDK2 and } \\
\text { cyclin D1. }\end{array}$ \\
\hline
\end{tabular}

$\uparrow:$ increased, $\downarrow$ : decreased, differentiation antagonizing noncoding RNA (DANCR), DNA methyltransferase 1 (DNMT1), DNA methyltransferase 3B (DNMT3B), domain containing 1-antisense (DCST1-AS1), eukaryotic translation initiation factor 2 subunit alpha (eIF2 $\alpha$ ), Fer-1-like family member 4 (FER1L4), FGD5-antisense RNA 1 (FGD5-AS1), fibroblast growth factor 2 (FGF2), hypoxia-inducible factor 3 alpha (HIF3A), Linc-RNA activator of myogenesis (Linc-RAM), lipopolysaccharide (LPS), MAF bZIP transcription factor G antisense RNA 1 (MAFGAS1), maternally expressed gene 3 (MEG3), metastasis-associated lung adenocarcinoma transcript 1 (MALAT1), MIR31 host gene (MIR31HG), mortal obligate RNA transcript (MORT), papillary thyroid carcinoma susceptibility candidate 3 (PTCSC3), periodontal ligament-associated protein-1 (PLAP-1), protein kinase-like endoplasmic reticulum kinase (PERK), protein kinase B (AKT), taurine-upregulated gene 1 (TUG1), toll-like receptors (TLR), tumor necrosis factor alpha (TNF- $\alpha)$. 


\section{Discussion}

This study systematically reviewed studies exploring the expression of lncRNAs and their role in the regulation of a variety of biological activities in PDL cells, such as osteogenesis and cell response to inflammation and mechanical stress. LncRNAs regulate gene expression at transcriptional and post-transcriptional levels. At the transcriptional level, lncRNAs may directly bind to DNA or act on transcriptional complexes, resulting in cis or trans gene activation or silencing [78,79]. LncRNAs can recognize and bind to complementary RNA sequences, which enables highly specific interactions that can regulate various post-transcriptional processes, such as mRNA splicing, transport, translation, and stabilization, thereby affecting various biological processes [78,80]. LncRNAs can also specifically recruit and integrate with RNA binding proteins (RBPs) to regulate their biological functions, thereby affecting the expression of downstream genes [81]. In addition to regulating mRNAs via independent mechanisms, lncRNAs can act as competing endogenous RNAs (ceRNAs) by competitively binding to miRNAs via miRNA response elements. This binding attenuates the ability of miRNAs to downregulate mRNA expression and thus indirectly regulates mRNA expression [82]. LncRNA-mediated ceRNA interactions have been identified in various cancers and inflammatory diseases, including periodontitis [83-85].

\subsection{Studies on IncRNA Expression Profiling in PDL Cells}

In the 13 studies that explored lncRNA expression profiles in PDL cells, 6 used microarray analysis and 7 used RNA-seq methods [27-30,35-43]. Recent developments in RNA-seq techniques offer enormous potential for transcriptome characterization as they are reliable tools for elucidating genetic and metabolic pathways involved in biological processes. RNA-seq provides more comprehensive information about the characteristics of transcripts as this information is not limited to the known genes represented on a microarray and novel transcription variants can be detected via alternative splicing [86].

Three of these thieteen studies compared lncRNA expression profiles in PDLSCs with the lncRNA expression profiles of other cell types, such as BMSCs, GMSCs, and DFCs $[27,42,43]$. Moreover, 5 of these 13 studies examined the lncRNA expression profiles of PDLSCs under osteogenic induction [28-30,35,36]. The results varied, showing differently up- and downregulated lncRNAs during the osteogenic differentiation process. These variations may be attributable to differences between samples and periods of induction. For example, Qu et al. [35] and Zhang et al. [29] examined three osteogenic-induced and three non-induced samples, whereas some authors did not mention the number of samples tested, and the period of osteogenic induction varied widely $(3,5,7$, or 14 days) between studies. It has been suggested that aging can affect the characteristics of the regenerative potentials of dental-derived stem cells $[87,88]$. Moreover, differences in library preparation, sequencing techniques, and methods of analysis may also have led to the variations in the results. Five of the thirteen studies explored the lncRNA profile of PDL cells subjected to mechanical stress [37-41]. Three of these studies applied tensile force on cells (10\% or $12 \%$ equibiaxial strain) $[37,39,40]$ and one applied compressive force on cells $\left(2 \mathrm{~g} / \mathrm{cm}^{2}\right)$ for $12 \mathrm{~h}$ [38]. After microarray or RNA-seq, most studies performed only PCR to validate the expression of several genes. Further in-depth studies are warranted to explore the regulation of the identified lncRNAs.

\subsection{Studies on IncRNAs Involved in the Osteogenic Differentiation of PDL Cells}

PDL cells are expected to play an important role in the clinical application of periodontal tissue regeneration as they offer new solutions for the treatment of periodontal diseases [19]. Studies have significantly expanded our knowledge of the potential regulatory role of lncRNAs in the osteogenic differentiation of PDL cells. Nineteen of the included studies explored the mechanism by which lncRNAs regulate the osteogenic differentiation of PDL cells [31-33,44-59]. The lncRNAs TUG1, prostate cancer-associated transcript 1 (PCAT1), X-inactive specific transcript (XIST), Fer-1-like family member 4 
(FER1L4), growth arrest-specific transcript 5 (GAS5), Prader Willi/Angelman region RNA 6 (PWAR6), osteogenesis impairment-related lncRNA of PDLSCs from periodontitis patients (lncRNA-POIR), Twist1, and antisense non-coding RNA in the inhibitor of cyclin-dependent kinase 4 (INK4) locus (ANRIL) have been reported to enhance osteogenic differentiation of PDL cells [32,45,48,50-52,55,56,58,59]. Whereas the lncRNAs ANCR, small molecule RNA host gene 1 (SNHG1), differentiation antagonizing non-coding RNA (DANCR), hypoxiainducible factor 1 alpha-antisense RNA 2 (HIF1A-AS2), exportin5 (XPO5), HOX transcript antisense RNA (HOTAIR), and homeobox A (HOXA) transcript at the distal tip (HOTTIP) have been reported to negatively correlate with the osteogenic differentiation of PDL cells $[31,44,46,47,53,54,57]$.

TUG1 was initially identified as an important gene in retinal development and the formation of photoreceptors [89]; later, it was reported to be abnormally expressed during tumorigenesis [90]. It was observed that TUG1 can bind to lin-28 homolog A, an RBP, thereby promoting the expression of osteogenesis-related markers and the osteogenic differentiation of PDLSCs [32]. Wu et al. reported a post-transcriptional regulatory mechanism by which TUG1 enhanced the osteogenic differentiation of PDLSCs: TUG1 sponges microRNA-222-3p, which promotes osteogenic differentiation by upregulating Smad 2/7, which are the main signal transducers for receptors of transforming growth factor beta. The knockdown of TUG1 or overexpression of microRNA-222-3p inhibited this upregulation [55]. MEG3, initially known as a tumor suppressor, is another lncRNA that has received much attention due to its association with the osteogenic differentiation of MSCs, DFCs, and PDL cells [33,49,91,92]. In PDL cells, MEG3 attenuates bone morphogenetic protein 2 (BMP2) expression by competing with BMP2 for binding to the RBP heterogeneous nuclear ribonucleoprotein I [49]. Furthermore, four studies have investigated the regulatory role of lncRNAs in the osteogenesis of P-PDL cells isolated from the extracted teeth of patients with periodontitis [33,45,50,58]. P-PDL cells were first isolated in 2010 and have since attracted much attention [93]. However, P-PDL cells have been shown to have less osteogenic differentiation potential than H-PDL cells [94-97]. Wang et al. used microarray analysis to identify a novel lncRNA, lncRNA-POIR, which is differentially expressed in P-PDLSCs. They found that LncRNA-POIR regulates Forkhead box O (FOXO)1 by sponging miR-182 and, thus, inhibits the canonical Wnt pathway and promotes osteogenesis [45].

\subsection{Studies on IncRNAs in PDL Cells Subjected to Inflammation, Mechanical Stress, and Other Stimuli}

Inflammation-stimulating factors released by bacteria, such as LPS and TNF- $\alpha$, activate the immune response in PDL cells, thereby aggravating the destruction of alveolar bone. Among the 18 studies that investigated the regulatory role of lncRNAs in PDL cells in response to inflammation and other stimuli, 6 studies compared the inflammatory responses of H-PDL and P-PDL cells [66-71], 7 studies stimulated PDL cells with LPS or/and TNF$\alpha$ to mimic periodontal inflammation [66,68-72,74], 3 studies stimulated PDL cells with mechanical stress [73-75], 1 study subjected PDL cells to hypoxia [76], and 1 study subjected cells to oxidative stress [77]. Under these stimuli, the biological activities of PDL cells, including cell proliferation, apoptosis, inflammatory responses, osteogenic differentiation, and autophagy, were explored.

LPS is an endotoxin and a major component of the cell membranes of Gram-negative bacteria, such as Porphyromonas gingivalis and Escherichia coli, where it performs various biological activities. It is mediated by the toll-like receptors (TLR) 2, and TLR4 and triggers cytokine-mediated immune-inflammatory responses in the host, which results in the release of a wide range of pro-inflammatory cytokines. Several lncRNAs, including TUG1, MEG3, metastasis-associated lung adenocarcinoma transcript 1 (MALAT1), FGD5-antisense RNA 1 (FGD5-AS1), and LINC01126, have been reported to modulate the inflammatory response of PDL cells to LPS challenge. Huang et al. and Han et al. reported that the expression of TUG1 is decreased in PDL cells upon LPS challenge, but they ascribed this to different regulatory mechanisms $[67,71]$. Han et al. reported that TUG1 competes with miR-132 
to promote the proliferation and inhibit the apoptosis of PDL cells under inflammatory stimuli [67]. More recently, Huang et al. suggested that TUG1 is a sponge of miR-498, which allows it to regulate the expression of RAR-related orphan receptor A and attenuate LPS-induced activation of the Wnt/beta-catenin pathway [71].

There has been extensive research on the regulatory mechanisms of orthodontic tooth movement. PDL cells subjected to mechanical stress are widely used to mimic in vivo conditions. Three lncRNAs, DANCR, MIR31 host gene (MIR31HG), and FER1L4, have been investigated for their role in the regulation of compressive force-induced biological activities in PDL cells [73-75]. It was suggested that the knockdown of DANCR inhibits the osteoclast formation and root resorption that is induced by compressive force via miR-34a-5p/jagged1 [73]. In addition, lncRNAs also regulate force-induced autophagy in PDL cells. For example, FER1L4 mediates compression-induced autophagy via the AKT/FOXO3 signaling pathway [75]. Notably, these studies have focused only on the effects of compressive stress on the regulation of lncRNAs in PDL cells; there have been no investigations on the effects of other types of stress loadings, such as tensile or shear forces, on the regulation of lncRNAs in PDL cells.

\subsection{Future Perspectives}

Non-coding RNAs possess critical biological functions that were initially discovered in cancer research and then in stem cell studies, and an increasing number of lncRNAs have been discovered in the field of regenerative medicine. With the rapid development of high-throughput sequencing, it is critical to screen diverse lncRNAs and further investigate their roles in various biological functions. With more in-depth research, lncRNAs and their target genes may be identified as possible therapeutic targets in clinically relevant diseases. This review summarizes current research on lncRNAs in PDL cells, with a focus on the expression profile of lncRNAs, their regulation of osteogenic differentiation and the effect upon stimulations. However, most of these recent developments are still in the in vitro stage, and clinical application remains a challenge.

\section{Conclusions}

PDL cells have significant potential for use in the clinical application of periodontal and bone regeneration. This study systematically reviewed studies exploring the expression and regulatory roles of lncRNAs in the diverse biological processes of PDL cells, such as osteogenic differentiation and cellular responses to inflammation, mechanical stress, and other stimuli. However, most of these studies were focused on in vitro analyses; more in vivo investigations are required in this promising translational field.

Supplementary Materials: The following supporting information can be downloaded at: https: / / www.mdpi.com/article/10.3390/biom12020304/s1, Table S1. Quality Assessment.

Author Contributions: Y.L. conceptualized the topic, collected the data, performed the statistical analysis, and wrote the manuscript. Z.T. collected the data, performed the statistical analysis, and wrote the manuscript. L.J. conceptualized the topic and supervised and facilitated the conduct of the study. Y.Y. participated in all stages of the review and supervised the conduct of the study. All authors critically revised the manuscript for important intellectual content and approved the final version of the manuscript.

Funding: This research received no external funding.

Institutional Review Board Statement: Not applicable.

Informed Consent Statement: Not applicable.

Data Availability Statement: Not applicable.

Conflicts of Interest: The authors declare no conflict of interest. 


\section{References}

1. Kinane, D.F.; Stathopoulou, P.G.; Papapanou, P.N. Periodontal diseases. Nat. Rev. Dis. Primers 2017, 3, 17038. [CrossRef] [PubMed]

2. Ramseier, C.A.; Anerud, A.; Dulac, M.; Lulic, M.; Cullinan, M.P.; Seymour, G.J.; Faddy, M.J.; Bürgin, W.; Schätzle, M.; Lang, N.P. Natural history of periodontitis: Disease progression and tooth loss over 40 years. J. Clin. Periodontol. 2017, 44, 1182-1191. [CrossRef] [PubMed]

3. Liu, J.; Ruan, J.; Weir, M.D.; Ren, K.; Schneider, A.; Wang, P.; Oates, T.W.; Chang, X.; Xu, H.H.K. Periodontal Bone-LigamentCementum, Regeneration via Scaffolds and Stem Cells. Cells 2019, 8, 537. [CrossRef]

4. Nuñez, J.; Vignoletti, F.; Caffesse, R.G.; Sanz, M. Cellular therapy in periodontal regeneration. Periodontology 2000 2019, 79, 107-116. [CrossRef] [PubMed]

5. McCulloch, C.A. Progenitor cell populations in the periodontal ligament of mice. Anat. Rec. 1985, 211, 258-262. [CrossRef] [PubMed]

6. McCulloch, C.A.; Bordin, S. Role of fibroblast subpopulations in periodontal physiology and pathology. J. Periodontal Res. 1991, 26, 144-154. [CrossRef] [PubMed]

7. Pitaru, S.; McCulloch, C.A.; Narayanan, S.A. Cellular origins and differentiation control mechanisms during periodontal development and wound healing. J. Periodontal Res. 1994, 29, 81-94. [CrossRef]

8. Lekic, P.; McCulloch, C.A. Periodontal ligament cell population: The central role of fibroblasts in creating a unique tissue. Anat. Rec. 1996, 245, 327-341. [CrossRef]

9. Lekic, P.; Rojas, J.; Birek, C.; Tenenbaum, H.; McCulloch, C.A. Phenotypic comparison of periodontal ligament cells in vivo and in vitro. J. Periodontal Res. 2001, 36, 71-79. [CrossRef]

10. Mattick, J.S.; Makunin, I.V. Non-coding RNA. Hum. Mol. Genet. 2006, 15, R17-R29. [CrossRef]

11. Gay, I.C.; Chen, S.; MacDougall, M. Isolation and characterization of multipotent human periodontal ligament stem cells. Orthod. Craniofac. Res. 2007, 10, 149-160. [CrossRef] [PubMed]

12. Seo, B.M.; Miura, M.; Gronthos, S.; Bartold, P.M.; Batouli, S.; Brahim, J.; Young, M.; Robey, P.G.; Wang, C.Y.; Shi, S. Investigation of multipotent postnatal stem cells from human periodontal ligament. Lancet 2004, 364, 149-155. [CrossRef]

13. Shi, S.; Bartold, P.M.; Miura, M.; Seo, B.M.; Robey, P.G.; Gronthos, S. The efficacy of mesenchymal stem cells to regenerate and repair dental structures. Orthod. Craniofac. Res. 2005, 8, 191-199. [CrossRef] [PubMed]

14. Kawanabe, N.; Murata, S.; Murakami, K.; Ishihara, Y.; Hayano, S.; Kurosaka, H.; Kamioka, H.; Takano-Yamamoto, T.; Yamashiro, $\mathrm{T}$. Isolation of multipotent stem cells in human periodontal ligament using stage-specific embryonic antigen-4. Differentiation 2010, 79, 74-83. [CrossRef]

15. Ng, T.K.; Yung, J.S.; Choy, K.W.; Cao, D.; Leung, C.K.; Cheung, H.S.; Pang, C.P. Transdifferentiation of periodontal ligamentderived stem cells into retinal ganglion-like cells and its microRNA signature. Sci. Rep. 2015, 5, 16429. [CrossRef]

16. Liu, Y.; Zheng, Y.; Ding, G.; Fang, D.; Zhang, C.; Bartold, P.M.; Gronthos, S.; Shi, S.; Wang, S. Periodontal ligament stem cell-mediated treatment for periodontitis in miniature swine. Stem Cells 2008, 26, 1065-1073. [CrossRef]

17. Liu, O.; Xu, J.; Ding, G.; Liu, D.; Fan, Z.; Zhang, C.; Chen, W.; Ding, Y.; Tang, Z.; Wang, S. Periodontal ligament stem cells regulate B lymphocyte function via programmed cell death protein 1. Stem Cells 2013, 31, 1371-1382. [CrossRef]

18. Iwasaki, K.; Akazawa, K.; Nagata, M.; Komaki, M.; Honda, I.; Morioka, C.; Yokoyama, N.; Ayame, H.; Yamaki, K.; Tanaka, Y.; et al. The Fate of Transplanted Periodontal Ligament Stem Cells in Surgically Created Periodontal Defects in Rats. Int. J. Mol. Sci. 2019, 20, 192. [CrossRef]

19. Feng, F.; Akiyama, K.; Liu, Y.; Yamaza, T.; Wang, T.M.; Chen, J.H.; Wang, B.B.; Huang, G.T.; Wang, S.; Shi, S. Utility of PDL progenitors for in vivo tissue regeneration: A report of 3 cases. Oral Dis. 2010, 16, 20-28. [CrossRef]

20. Romano, G.; Veneziano, D.; Acunzo, M.; Croce, C.M. Small non-coding RNA and cancer. Carcinogenesis 2017, 38, 485-491. [CrossRef]

21. Ponjavic, J.; Ponting, C.P.; Lunter, G. Functionality or transcriptional noise? Evidence for selection within long noncoding RNAs. Genome Res. 2007, 17, 556-565. [CrossRef] [PubMed]

22. Cao, J. The functional role of long non-coding RNAs and epigenetics. Biol. Proced. Online 2014, 16, 11. [CrossRef]

23. Niland, C.N.; Merry, C.R.; Khalil, A.M. Emerging Roles for Long Non-Coding RNAs in Cancer and Neurological Disorders. Front. Genet. 2012, 3, 25. [CrossRef]

24. Yang, G.; Lu, X.; Yuan, L. LncRNA: A link between RNA and cancer. Biochim. Biophys. Acta 2014, 1839, 1097-1109. [CrossRef] [PubMed]

25. Wu, G.C.; Pan, H.F.; Leng, R.X.; Wang, D.G.; Li, X.P.; Li, X.M.; Ye, D.Q. Emerging role of long noncoding RNAs in autoimmune diseases. Autoimmun. Rev. 2015, 14, 798-805. [CrossRef] [PubMed]

26. Lorenzen, J.M.; Thum, T. Long noncoding RNAs in kidney and cardiovascular diseases. Nat. Rev. Nephrol. 2016, 12, 360-373. [CrossRef]

27. Dong, R.; Du, J.; Wang, L.; Wang, J.; Ding, G.; Wang, S.; Fan, Z. Comparison of long noncoding RNA and mRNA expression profiles in mesenchymal stem cells derived from human periodontal ligament and bone marrow. Biomed. Res. Int 2014, 2014, 317853. [CrossRef]

28. Gu, X.; Li, M.; Jin, Y.; Liu, D.; Wei, F. Identification and integrated analysis of differentially expressed lncRNAs and circRNAs reveal the potential ceRNA networks during PDLSC osteogenic differentiation. BMC Genet. 2017, 18, 100. [CrossRef] 
29. Zhang, Q.; Chen, L.; Cui, S.; Li, Y.; Zhao, Q.; Cao, W.; Lai, S.; Yin, S.; Zuo, Z.; Ren, J. Expression and regulation of long noncoding RNAs during the osteogenic differentiation of periodontal ligament stem cells in the inflammatory microenvironment. Sci. Rep. 2017, 7, 13991. [CrossRef]

30. Zheng, Y.; Li, X.; Huang, Y.; Jia, L.; Li, W. Time series clustering of mRNA and lncRNA expression during osteogenic differentiation of periodontal ligament stem cells. PeerJ 2018, 6, e5214. [CrossRef]

31. Jia, Q.; Jiang, W.; Ni, L. Down-regulated non-coding RNA (lncRNA-ANCR) promotes osteogenic differentiation of periodontal ligament stem cells. Arch. Oral Biol. 2015, 60, 234-241. [CrossRef] [PubMed]

32. He, Q.; Yang, S.; Gu, X.; Li, M.; Wang, C.; Wei, F. Long noncoding RNA TUG1 facilitates osteogenic differentiation of periodontal ligament stem cells via interacting with Lin28A. Cell Death Dis. 2018, 9, 455. [CrossRef] [PubMed]

33. Liu, Y.; Liu, C.; Zhang, A.; Yin, S.; Wang, T.; Wang, Y.; Wang, M.; Liu, Y.; Ying, Q.; Sun, J.; et al. Down-regulation of long non-coding RNA MEG3 suppresses osteogenic differentiation of periodontal ligament stem cells (PDLSCs) through miR-27a-3p/IGF1 axis in periodontitis. Aging 2019, 11, 5334-5350. [CrossRef] [PubMed]

34. Wells, K.; Littell, J.H. Study quality assessment in systematic reviews of research on intervention effects. Res. Soc. Work Pr. 2008, 19, 52-62. [CrossRef]

35. Qu, Q.; Fang, F.; Wu, B.; Hu, Y.; Chen, M.; Deng, Z.; Ma, D.; Chen, T.; Hao, Y.; Ge, Y. Potential Role of Long Non-Coding RNA in Osteogenic Differentiation of Human Periodontal Ligament Stem Cells. J. Periodontol. 2016, 87, e127-e137. [CrossRef]

36. Xie, L.; Chen, J.; Ren, X.; Zhang, M.; Thuaksuban, N.; Nuntanaranont, T.; Guan, Z. Alteration of circRNA and lncRNA expression profile in exosomes derived from periodontal ligament stem cells undergoing osteogenic differentiation. Arch. Oral Biol. 2021, 121, 104984. [CrossRef]

37. Guo, X.; Wang, J.; Chen, J. Identification of Aberrantly Expressed lncRNAs Involved in Orthodontic Force Using a Subpathway Strategy. Comput. Math. Methods Med. 2019, 2019, 9250129. [CrossRef]

38. Huang, Y.; Zhang, Y.; Li, X.; Liu, H.; Yang, Q.; Jia, L.; Zheng, Y.; Li, W. The long non-coding RNA landscape of periodontal ligament stem cells subjected to compressive force. Eur. J. Orthod. 2019, 41, 333-342. [CrossRef]

39. Lin, Y.; Cheng, T.; Zhu, S.; Gu, M.; Jin, L.; Yang, Y. mRNA and long non-coding RNA expression profiling of human periodontal ligament cells under tension loading. Eur. J. Orthod. 2021, 43, 698-707. [CrossRef]

40. Liu, J.; Zhao, Y.; Niu, Q.; Qiu, N.; Liu, S.; Li, C.; Li, C.; Miao, P.; Yan, L.; Li, Q.; et al. Long Noncoding RNA Expression Profiles of Periodontal Ligament Stem Cells from the Periodontitis, Microenvironment in Response to Static, Mechanical Strain. Stem Cells Int. 2021, 2021, 6655526. [CrossRef]

41. Wang, H.; Feng, C.; Li, M.; Zhang, Z.; Liu, J.; Wei, F. Analysis of lncRNAs-miRNAs-mRNAs networks in periodontal ligament stem cells under mechanical force. Oral Dis. 2021, 27, 325-337. [CrossRef]

42. Jia, L.; Zhang, Y.; Ji, Y.; Li, X.; Xing, Y.; Wen, Y.; Huang, H.; Xu, X. Comparative analysis of lncRNA and mRNA expression profiles between periodontal ligament stem cells and gingival mesenchymal stem cells. Gene 2019, 699, 155-164. [CrossRef]

43. Wu, L.; Deng, L.; Hong, H.; Peng, C.; Zhang, X.; Chen, Z.; Ling, J. Comparison of long non-coding RNA expression profiles in human dental follicle cells and human periodontal ligament cells. Mol. Med. Rep. 2019, 20, 939-950. [CrossRef]

44. Jia, Q.; Chen, X.; Jiang, W.; Wang, W.; Guo, B.; Ni, L. The Regulatory Effects of Long Noncoding RNA-ANCR on Dental Tissue-Derived Stem Cells. Stem Cells Int. 2016, 2016, 3146805. [CrossRef] [PubMed]

45. Wang, L.; Wu, F.; Song, Y.; Li, X.; Wu, Q.; Duan, Y.; Jin, Z. Long noncoding RNA related to periodontitis interacts with miR-182 to upregulate osteogenic differentiation in periodontal mesenchymal stem cells of periodontitis patients. Cell Death Dis. 2016, 7, e2327. [CrossRef] [PubMed]

46. Chen, D.; Wu, L.; Liu, L.; Gong, Q.; Zheng, J.; Peng, C.; Deng, J. Comparison of HIF1A-AS1 and HIF1A-AS2 in regulating HIF-1 $\alpha$ and the osteogenic differentiation of PDLCs under hypoxia. Int. J. Mol. Med. 2017, 40, 1529-1536. [CrossRef] [PubMed]

47. Peng, W.; Deng, W.; Zhang, J.; Pei, G.; Rong, Q.; Zhu, S. Long noncoding RNA ANCR suppresses bone formation of periodontal ligament stem cells via sponging miRNA-758. Biochem. Biophys. Res. Commun. 2018, 503, 815-821. [CrossRef]

48. Jia, B.; Qiu, X.; Chen, J.; Sun, X.; Zheng, X.; Zhao, J.; Li, Q.; Wang, Z. A feed-forward regulatory network lncPCAT1/miR-106a5p/E2F5 regulates the osteogenic differentiation of periodontal ligament stem cells. J. Cell. Physiol. 2019, 234, 19523-19538. [CrossRef]

49. Liu, Y.; Zeng, X.; Miao, J.; Liu, C.; Wei, F.; Liu, D.; Zheng, Z.; Ting, K.; Wang, C.; Guo, J. Upregulation of long noncoding RNA MEG3 inhibits the osteogenic differentiation of periodontal ligament cells. J. Cell. Physiol. 2019, 234, 4617-4626. [CrossRef]

50. Xu, Y.; Qin, W.; Guo, D.; Liu, J.; Zhang, M.; Jin, Z. LncRNA-TWIST1 Promoted Osteogenic Differentiation Both in PPDLSCs and in HPDLSCs by Inhibiting TWIST1 Expression. Biomed. Res. Int. 2019, 2019, 8735952. [CrossRef]

51. Feng, Y.; Wan, P.; Yin, L. Long Noncoding RNA X-Inactive Specific Transcript (XIST) Promotes Osteogenic Differentiation of Periodontal Ligament Stem Cells by Sponging MicroRNA-214-3p. Med. Sci. Monit. 2020, 26, e918932. [CrossRef] [PubMed]

52. Huang, Y.; Han, Y.; Guo, R.; Liu, H.; Li, X.; Jia, L.; Zheng, Y.; Li, W. Long non-coding RNA FER1L4 promotes osteogenic differentiation of human periodontal ligament stromal cells via miR-874-3p and vascular endothelial growth factor A. Stem Cell Res. 2020, 11, 5. [CrossRef] [PubMed]

53. Li, Z.; Guo, X.; Wu, S. Epigenetic silencing of KLF2 by long non-coding RNA SNHG1 inhibits periodontal ligament stem cell osteogenesis differentiation. Stem Cell Res. 2020, 11, 435. [CrossRef] [PubMed]

54. Wang, Z.; Huang, Y.; Tan, L. Downregulation of lncRNA DANCR promotes osteogenic differentiation of periodontal ligament stem cells. BMC Dev. Biol. 2020, 20, 2. [CrossRef] 
55. Wu, D.; Yin, L.; Sun, D.; Wang, F.; Wu, Q.; Xu, Q.; Xin, B. Long noncoding RNA TUG1 promotes osteogenic differentiation of human periodontal ligament stem cell through sponging microRNA-222-3p to negatively regulate Smad2/7. Arch. Oral Biol. 2020, 117, 104814. [CrossRef] [PubMed]

56. Yang, Q.; Han, Y.; Liu, P.; Huang, Y.; Li, X.; Jia, L.; Zheng, Y.; Li, W. Long Noncoding RNA GAS5 Promotes Osteogenic Differentiation of Human Periodontal Ligament Stem Cells by Regulating GDF5 and p38/JNK Signaling Pathway. Front. Pharm. 2020, 11, 701. [CrossRef] [PubMed]

57. Assis, R.I.F.; Feltran, G.D.S.; Silva, M.E.S.; Palma, I.; Rovai, E.S.; Miranda, T.B.; Ferreira, M.R.; Zambuzzi, W.F.; Birbrair, A.; Andia, D.C.; et al. Non-coding RNAs repressive role in post-transcriptional processing of RUNX2 during the acquisition of the osteogenic phenotype of periodontal ligament mesenchymal stem cells. Dev. Biol. 2021, 470, 37-48. [CrossRef]

58. Bian, M.; Yu, Y.; Li, Y.; Zhou, Z.; Wu, X.; Ye, X.; Yu, J. Upregulating the Expression of LncRNA ANRIL Promotes Osteogenesis via the miR-7-5p/IGF-1R Axis in the Inflamed Periodontal Ligament Stem Cells. Front. Cell Dev. Biol. 2021, 9, 604400. [CrossRef]

59. Xiang, J.; Bian, Y. PWAR6 interacts with miR-106a-5p to regulate the osteogenic differentiation of human periodontal ligament stem cells. Mol. Med. Rep. 2021, 23, 268. [CrossRef]

60. Chen, P.; Huang, Y.; Wang, Y.; Li, S.; Chu, H.; Rong, M. MALAT1 overexpression promotes the proliferation of human periodontal ligament stem cells by upregulating fibroblast growth factor 2. Exp. Med. 2019, 18, 1627-1632. [CrossRef]

61. Liu, W.; Zheng, Y.; Chen, B.; Ke, T.; Shi, Z. LncRNA papillary thyroid carcinoma susceptibility candidate 3 (PTCSC3) regulates the proliferation of human periodontal ligament stem cells and toll-like receptor 4 (TLR4) expression to improve periodontitis. BMC Oral Health 2019, 19, 108. [CrossRef] [PubMed]

62. Wang, Y.; Sun, Y.; Zheng, P.; Cai, C.; Jiang, Y.; Zhang, H.; Li, Z.; Cai, Q. Long non-coding RNAs mortal obligate RNA transcript regulates the proliferation of human periodontal ligament stem cells and affects the recurrence of periodontitis. Arch. Oral Biol. 2019, 105, 1-4. [CrossRef] [PubMed]

63. Wangzhou, K.; Gong, L.; Liu, C.; Tan, Y.; Chen, J.; Li, C.; Lai, Z.; Hao, C. LncRNA MAFG-AS1 regulates human periodontal ligament stem cell proliferation and Toll-like receptor 4 expression. Oral Dis. 2020, 26, 1302-1307. [CrossRef]

64. Wu, X.; Cao, Z.; Chen, H.; Ou, Q.; Huang, X.; Wang, Y. Downregulation of Linc-RNA activator of myogenesis lncRNA participates in FGF2-mediated proliferation of human periodontal ligament stem cells. J. Periodontol. 2020, 91, 422-427. [CrossRef]

65. Wang, X.; Wang, Y. LncRNA DCST1-AS1 inhibits PDLCs' proliferation in periodontitis and may bind with miR-21 precursor to upregulate PLAP-1. J. Periodontal Res. 2021, 56, 256-264. [CrossRef]

66. Chen, H.; Lan, Z.; Li, Q.; Li, Y. Abnormal expression of long noncoding RNA FGD5-AS1 affects the development of periodontitis through regulating miR-142-3p/SOCS6/NF-кB pathway. Artif. Cells Nanomed. Biotechnol. 2019, 47, 2098-2106. [CrossRef] [PubMed]

67. Han, Y.; Wang, F.; Shao, L.; Huang, P.; Xu, Y. LncRNA TUG1 mediates lipopolysaccharide-induced proliferative inhibition and apoptosis of human periodontal ligament cells by sponging miR-132. Acta Biochim. Biophys. Sin. 2019, 51, 1208-1215. [CrossRef]

68. Dong, Y.; Feng, S.; Dong, F. Maternally-Expressed, Gene 3 (MEG3)/miR-143-3p Regulates, Injury to Periodontal Ligament Cells by Mediating the AKT/Inhibitory kB Kinase (IKK) Pathway. Med. Sci. Monit. 2020, 26, e922486. [CrossRef]

69. Zhu, Y.; Ai, R.; Ding, Z.; He, Q.; Zhang, X.; Dong, Y.; He, Y. LncRNA-01126 inhibits the migration of human periodontal ligament cells through MEK/ERK signaling pathway. J. Periodontal Res. 2020, 55, 631-641. [CrossRef]

70. Chen, Q.; Cao, M.; Ge, H. Knockdown of MALAT1 Inhibits the Progression of Chronic, Periodontitis via Targeting miR-7695p/HIF3A Axis. BioMed Res. Int. 2021, 2021, 8899863. [CrossRef]

71. Huang, N.; Li, C.; Sun, W.; Wu, J.; Xiao, F. Long non-coding RNA TUG1 participates in LPS-induced periodontitis by regulating miR-498/RORA pathway. Oral Dis. 2021, 27, 600-610. [CrossRef] [PubMed]

72. Guo, R.; Huang, Y.; Liu, H.; Zheng, Y.; Jia, L.; Li, W. Long Non-Coding RNA H19 Participates in Periodontal Inflammation via Activation of Autophagy. J. Inflamm. Res. 2020, 13, 635-646. [CrossRef] [PubMed]

73. Zhang, X.; Zhao, Y.; Zhao, Z.; Han, X.; Chen, Y. Knockdown of DANCR reduces osteoclastogenesis and root resorption induced by compression force via Jagged1. Cell Cycle 2019, 18, 1759-1769. [CrossRef] [PubMed]

74. Han, Y.; Yang, Q.; Huang, Y.; Li, X.; Zhu, Y.; Jia, L.; Zheng, Y.; Li, W. Mechanical force inhibited hPDLSCs proliferation with the downregulation of MIR31HG via DNA methylation. Oral Dis. 2021, 27, 1268-1282. [CrossRef]

75. Huang, Y.; Liu, H.; Guo, R.; Han, Y.; Yang, Y.; Zhao, Y.; Zheng, Y.; Jia, L.; Li, W. Long Non-coding RNA FER1L4 Mediates the Autophagy of Periodontal Ligament Stem Cells Under Orthodontic Compressive Force via AKT/FOXO3 Pathway. Front. Cell Dev. Biol. 2021, 9, 631181. [CrossRef]

76. Zhou, M.; Hu, H.; Han, Y.; Li, J.; Zhang, Y.; Tang, S.; Yuan, Y.; Zhang, X. Long non-coding RNA 01126 promotes periodontitis pathogenesis of human periodontal ligament cells via miR-518a-5p/HIF-1 $\alpha$ /MAPK pathway. Cell Prolif. 2021, 54, e12957. [CrossRef]

77. Shi, B.; Shao, B.; Yang, C.; Guo, Y.; Fu, X.; Gan, N. Upregulation of JHDM1D-AS1 protects PDLSCs from $\mathrm{H}_{2} \mathrm{O}_{2}$-induced apoptosis by decreasing DNAJC10 via phosphorylation of eIF2 $\alpha$. Biochimie 2019, 165, 48-56. [CrossRef]

78. Mercer, T.R.; Dinger, M.E.; Mattick, J.S. Long non-coding RNAs: Insights into functions. Nat. Rev. Genet. 2009, 10, 155-159. [CrossRef]

79. Dykes, I.M.; Emanueli, C. Transcriptional and Post-transcriptional Gene Regulation by Long Non-coding RNA. Genom. Proteom. Bioinform. 2017, 15, 177-186. [CrossRef] 
80. He, R.Z.; Luo, D.X.; Mo, Y.Y. Emerging roles of lncRNAs in the post-transcriptional regulation in cancer. Genes Dis. 2019, 6, 6-15. [CrossRef]

81. Kim, C.; Kang, D.; Lee, E.K.; Lee, J.S. Long Noncoding RNAs and RNA-Binding Proteins in Oxidative Stress, Cellular Senescence, and Age-Related Diseases. Oxid. Med. Cell Longev. 2017, 2017, 2062384. [CrossRef]

82. Salmena, L.; Poliseno, L.; Tay, Y.; Kats, L.; Pandolfi, P.P. A ceRNA hypothesis: The Rosetta Stone of a hidden RNA language? Cell 2011, 146, 353-358. [CrossRef]

83. Karreth, F.A.; Pandolfi, P.P. ceRNA cross-talk in cancer: When ce-bling rivalries go awry. Cancer Discov. 2013, 3, 1113-1121. [CrossRef]

84. Sun, F.; Liang, W.; Tang, K.; Hong, M.; Qian, J. Profiling the lncRNA-miRNA-mRNA ceRNA network to reveal potential crosstalk between inflammatory bowel disease and colorectal cancer. PeerJ 2019, 7, e7451. [CrossRef]

85. Lin, Y.; Jin, L.; Tong, W.M.; Leung, Y.Y.; Gu, M.; Yang, Y. Identification and integrated analysis of differentially expressed long non-coding RNAs associated with periodontitis in humans. J. Periodontal Res. 2021, 56, 679-689. [CrossRef]

86. Wang, Z.; Gerstein, M.; Snyder, M. RNA-Seq: A revolutionary tool for transcriptomics. Nat. Rev. Genet. 2009, 10, 57-63. [CrossRef]

87. Zheng, W.; Wang, S.; Ma, D.; Tang, L.; Duan, Y.; Jin, Y. Loss of proliferation and differentiation capacity of aged human periodontal ligament stem cells and rejuvenation by exposure to the young extrinsic environment. Tissue Eng. Part A 2009, 15, $2363-2371$. [CrossRef]

88. Bhandi, S.; Alkahtani, A.; Reda, R.; Mashyakhy, M.; Boreak, N.; Maganur, P.C.; Vishwanathaiah, S.; Mehta, D.; Vyas, N.; Patil, V.; et al. Parathyroid Hormone Secretion and Receptor Expression Determine the Age-Related Degree of Osteogenic Differentiation in Dental Pulp Stem Cells. J. Pers. Med. 2021, 11, 349. [CrossRef]

89. Young, T.L.; Matsuda, T.; Cepko, C.L. The noncoding RNA taurine upregulated gene 1 is required for differentiation of the murine retina. Curr. Biol. 2005, 15, 501-512. [CrossRef]

90. Ghaforui-Fard, S.; Vafaee, R.; Taheri, M. Taurine-upregulated gene 1: A functional long noncoding RNA in tumorigenesis. J. Cell. Physiol 2019, 234, 17100-17112. [CrossRef]

91. Deng, L.; Hong, H.; Zhang, X.; Chen, D.; Chen, Z.; Ling, J.; Wu, L. Down-regulated lncRNA MEG3 promotes osteogenic differentiation of human dental follicle stem cells by epigenetically regulating Wnt pathway. Biochem. Biophys. Res. Commun. 2018, 503, 2061-2067. [CrossRef]

92. Zhuang, W.; Ge, X.; Yang, S.; Huang, M.; Zhuang, W.; Chen, P.; Zhang, X.; Fu, J.; Qu, J.; Li, B. Upregulation of lncRNA MEG3 Promotes, Osteogenic Differentiation of Mesenchymal, Stem Cells from Multiple, Myeloma Patients by Targeting, BMP4 Transcription. Stem Cells 2015, 33, 1985-1997. [CrossRef]

93. El-Awady, A.R.; Messer, R.L.; Gamal, A.Y.; Sharawy, M.M.; Wenger, K.H.; Lapp, C.A. Periodontal ligament fibroblasts sustain destructive immune modulators of chronic periodontitis. J. Periodontol. 2010, 81, 1324-1335. [CrossRef]

94. Xia, Y.; Tang, H.N.; Wu, R.X.; Yu, Y.; Gao, L.N.; Chen, F.M. Cell Responses to Conditioned, Media Produced by Patient-Matched, Stem Cells, Derived from Healthy and Inflamed, Periodontal Ligament, Tissues. J. Periodontol. 2016, 87, e53-e63. [CrossRef]

95. Tang, H.N.; Xia, Y.; Yu, Y.; Wu, R.X.; Gao, L.N.; Chen, F.M. Stem cells derived from "inflamed" and healthy periodontal ligament tissues and their sheet functionalities, a patient-matched comparison. J. Clin. Periodontol. 2016, 43, 72-84. [CrossRef]

96. Liu, D.; Xu, J.; Liu, O.; Fan, Z.; Liu, Y.; Wang, F.; Ding, G.; Wei, F.; Zhang, C.; Wang, S. Mesenchymal stem cells derived from inflamed periodontal ligaments exhibit impaired immunomodulation. J. Clin. Periodontol. 2012, 39, 1174-1182. [CrossRef]

97. Park, J.C.; Kim, J.M.; Jung, I.H.; Kim, J.C.; Choi, S.H.; Cho, K.S.; Kim, C.S. Isolation and characterization of human periodontal ligament (PDL) stem cells (PDLSCs) from the inflamed PDL tissue: In vitro and in vivo evaluations. J. Clin. Periodontol. 2011, 38 , 721-731. [CrossRef] 